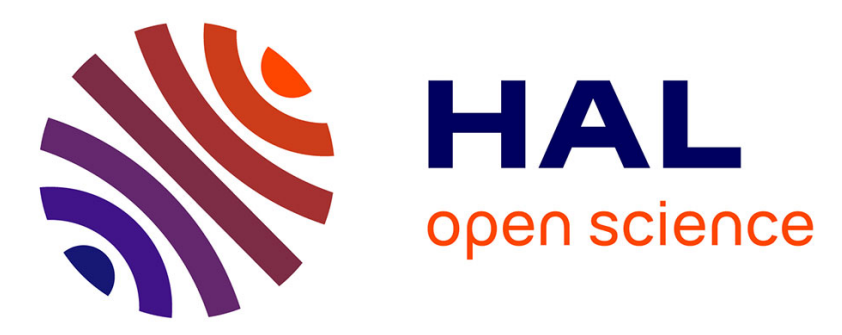

\title{
Shear wave splitting in SE Brazil: an effect of active or fossil upper mantle flow, or both?
}

Maggy Heintz, Alain Vauchez, Marcelo Assumpçao, Guilhem Barruol, Marcos Egydio-Silva

\section{- To cite this version:}

Maggy Heintz, Alain Vauchez, Marcelo Assumpçao, Guilhem Barruol, Marcos Egydio-Silva. Shear wave splitting in SE Brazil: an effect of active or fossil upper mantle flow, or both?. Earth and Planetary Science Letters, 2003, 211 (1-2), pp.79-95. 10.1016/S0012-821X(03)00163-8 hal-01389116

\section{HAL Id: hal-01389116 \\ https://hal.univ-reunion.fr/hal-01389116}

Submitted on 28 Oct 2016

HAL is a multi-disciplinary open access archive for the deposit and dissemination of scientific research documents, whether they are published or not. The documents may come from teaching and research institutions in France or abroad, or from public or private research centers.
L'archive ouverte pluridisciplinaire HAL, est destinée au dépôt et à la diffusion de documents scientifiques de niveau recherche, publiés ou non, émanant des établissements d'enseignement et de recherche français ou étrangers, des laboratoires publics ou privés. 


\title{
Shear wave splitting in SE Brazil: an effect of active or fossil upper mantle flow, or both?
}

\author{
Maggy Heintz ${ }^{\mathrm{a}, *}$, Alain Vauchez ${ }^{\mathrm{a}}$, Marcelo Assumpção ${ }^{\mathrm{b}}$, Guilhem Barruol $^{\mathrm{a}, 1}$, \\ Marcos Egydio-Silva ${ }^{c}$
}

a Laboratoire de Tectonophysique, Université Montpellier II, 1 Place Eugène Bataillon, Case Courrier 049, 34095 Montpellier, France

b Instituto de Astronomia e Geofisica, Departamento de Geofísica, São Paulo, Brazil

c Universidade de São Paulo, Rua do Lago 562, CEP 05508-900 São Paulo, Brazil

Received 26 September 2002; received in revised form 6 March 2003; accepted 11 March 2003

\begin{abstract}
We investigated the structure of the upper mantle beneath southeastern Brazil using teleseismic shear wave splitting measurements. Measurements were performed on seismic data recorded in the Ribeira and Brasilia Neoproterozoic belts, which wrap around the southern termination of the São Francisco craton and disappear westward under the Paraná basin. In the northern Ribeira belt, dominated by thrust tectonics, the fast shear wave polarization planes trend on average $\mathrm{N} 080^{\circ} \mathrm{E}$, whereas in the central domain, dominated by strike-slip tectonics, fast shear waves are polarized parallel to the structural trend $\left(\mathrm{N} 065^{\circ} \mathrm{E}\right)$. Stations located above the main transcurrent fault display large delay times $(>2.5 \mathrm{~s})$. Such values, among the largest in the world, require either an unusually large intrinsic anisotropy frozen within the lithosphere, or a contribution from both the lithospheric and asthenospheric mantle. Within the southern Brasilia belt, fast split shear waves are polarized parallel to the structural trend of the belt, at a high angle from the APM. Although part of our data set strongly favors an origin of anisotropy related to a fabric frozen in the lithospheric mantle since the Neoproterozoic, a contribution of the asthenospheric flow related to the present day plate motion is also required to explain the observed splitting parameters.
\end{abstract}

Keywords: seismic anisotropy; orogenic lithosphere; SE Brazil; crust-mantle coupling; lithospheric-scale faults; shear wave splitting

* Corresponding author.

E-mail addresses: heintz@dstu.univ-montp2.fr (M. Heintz), vauchez@dstu.univ-montp2.fr (A. Vauchez), marcelo@iag.usp.br (M. Assumpção), barruol@upf.pf (G. Barruol), megydios@usp.br (M. Egydio-Silva).

* Supplementary data associated with this article can be found at doi:10.1016/S0012-821X(03)00163-8

1 Present address: Jeune Equipe Terre Océan, Université de Polynésie Française, BP 6570, Faaa Aéroport, Tahiti, Polynesie Francaise.

\section{Introduction}

The tectonic behavior of the continental upper mantle during orogenesis still remains poorly understood. The question of the mechanical coupling/uncoupling of the crust and the mantle during the deformation of the continental lithosphere represents a key issue to improve our understanding of the geodynamics of continents. Shear wave splitting measurements provide an opportunity to 
investigate the upper mantle structure (see, e.g., $[1,2]$ for review), because the splitting parameters retrieved from the data are closely related to the crystallographic fabric developed due to past or present mantle flow [3-6]. Comparison of core shear wave polarization anisotropy and surface geology may therefore provide insights into the coherence of the deformation across the lithosphere in orogenic domains.

Shear wave splitting measurements have been performed in southeastern Brazil over an area of ca. $100000 \mathrm{~km}^{2}$ that encompasses several tectonic domains of contrasted age and structure: the southern termination of the São Francisco craton, surrounded by the Ribeira and Brasilia mobile belts, both partially buried southwestward under the Paraná large igneous province. The southerncentral Ribeira belt is of special interest since a network of lithospheric-scale wrench faults $[7,8]$ dominates its tectonic fabric. An efficient crustmantle coupling might occur in major intracontinental transcurrent faults resulting in a polarization of the fast split shear wave parallel to the trend of the faults [9]. In addition, receiver functions analysis [10] suggests that the eastern margin of the continent was thinned during the South Atlantic initial rifting, $140 \mathrm{Myr}$ ago, raising the question of the effect of this event on the fabric and anisotropy of the old continental lithosphere.

Seismic anisotropy and the splitting of teleseismic shear waves are commonly observed in continental areas. The anisotropy of rock elastic properties may have various origins (see, e.g., [4]). There is, however, a consensus that anisotropy observed in teleseismic shear waves mostly results from the lattice-preferred orientation (LPO) of rock-forming minerals in the mantle $[1,11,12]$. The seismic anisotropy recorded at the Earth's surface represents a vertically integrated effect of anisotropy from the core-mantle boundary to the surface. It is thus impossible to directly determine the depth of the anisotropy source. For vertically propagating shear waves, although small contributions from the $\mathrm{D}^{\prime \prime}$ layer [13], the lower mantle [14] and the crust [15-17] cannot be ruled out, the main source of the observed seismic anisotropy is restricted between the $410 \mathrm{~km}$ olivine-spinel phase transition and the Moho [1,2,18]. Surface wave tomographic models including anisotropic parameters provide, however, tighter constraints on the depth of anisotropy. For instance, an automated Rayleigh waveform inversion has shown that most of the anisotropy is restricted within the first $200 \mathrm{~km}$ beneath the South American continent [19].

In the upper mantle, the most abundant and easily deformable mineral is olivine, whose LPO is probably responsible for the anisotropy observed in teleseismic waves. Two models have been proposed: either olivine LPO results from the active deformation of the asthenospheric mantle that accommodates absolute plate motion $[11,20]$, or it developed during the past deformation, then was 'frozen' in the lithosphere during post-tectonic thermal relaxation [1,21-25]. Lithospheric mantle xenoliths systematically display an olivine LPO [26], suggesting that anisotropy is a pervasive and ubiquitous feature of the lithospheric mantle that can be preserved over a very long period. On the other hand, numerical models of the sublithospheric mantle deformation that accommodates plate motion show that a LPO, and thus an elastic anisotropy, can be generated in the asthenosphere [27].

When a polarized S-wave propagates across an anisotropic medium (e.g. a textured upper mantle), it is split into two quasi S-waves that are polarized in two orthogonal planes and propagate at different velocities. Shear wave splitting is therefore characterized by two parameters: $\phi$, the orientation of the plane in which the fast split wave is polarized, and $\mathrm{d} t$, the delay between the arrival times of the fast and slow split waves. Petrophysical studies have shown that $\phi$ is a proxy of the orientation of the [100] axis of olivine (assumed to be statistically parallel to the flow direction [5]). The delay time depends on the intrinsic anisotropy, the thickness of the anisotropic layer, the orientation of the ray path with respect to the elastic matrix of the anisotropic medium, and the vertical coherence of the mantle fabric. The relatively simple relationships between splitting parameters and the crystallographic fabric of mantle rocks have made shear wave splitting a useful tool to investigate upper mantle deformation [28]. In continental areas, shear wave splitting measure- 
ment is commonly performed on teleseismic S-waves such as SKS, SKKS or PKS phases. These phases are generated from a P-to-S conversion at the core-mantle boundary. They are thus polarized along the radial direction and arrive at the station with a nearly vertical incidence. The presence of energy on the transverse component together with an elliptical particles motion in the horizontal plane indicate that $\mathrm{S}$-waves propagated across an anisotropic medium on their way up to the surface.

\section{Geological setting}

The geology of southeastern Brazil spans from the Archean to the Cenozoic (Fig. 1). The Southern São Francisco craton comprises 2.7-3.3-Gyrold terrains and was stabilized at ca. $1.5 \mathrm{Gyr}$. It is surrounded by two slightly diachronic Neoproterozoic belts: (1) at the southwestern edge of the craton, the NW-SE-trending southern Brasilia belt, which results from the convergence of the Amazon and São Francisco cratons, and was stabilized at ca. $620 \mathrm{Myr}$, and (2) the Ribeira-Araçuaí belt, which stretches along the eastern edge of the craton. The Ribeira-Araçuaí, and its African counterpart, the West-Congo orogen [29], formed during the final amalgamation stage of western Gondwana (580-540 Myr), then split during the South Atlantic rifting (140 Myr).

The structural trend of the Ribeira-Araçuaí

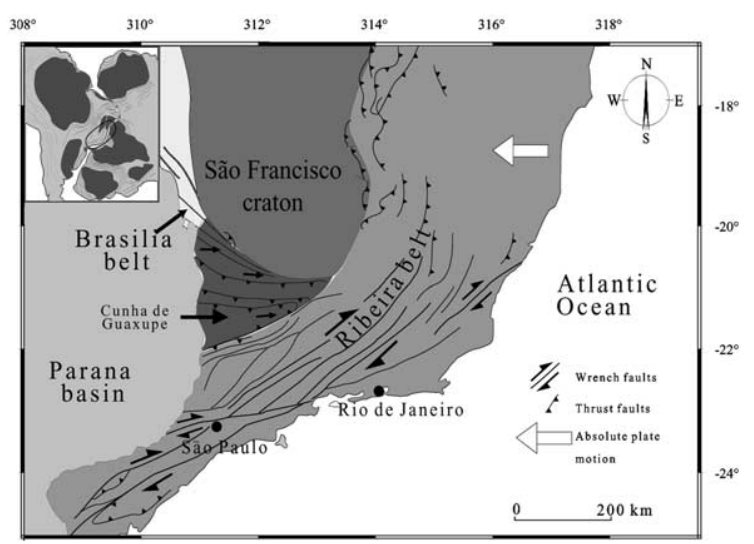

Fig. 1. Cartoon showing the main geological subdivisions of southeastern Brazil. belt changes at ca. $21^{\circ} \mathrm{S}$ latitude, from NNE or NS within the northern domain, to ENE in the southern domain. This curvature is spatially correlated to the southern termination of the São Francisco craton. The change in structural trend is associated with a major variation in the tectonic style along the belt. Indeed, the northern domain is dominated by thrusting towards the craton whereas transpressional wrench faulting dominates in the central domain.

In between the southern Brasilia and Ribeira mobile belts lies the 'Cunha de Guaxupè' (or Guaxupè syntaxis), a giant allochton that involves a composite section of Neoproterozoic deep continental crust, equivalent to the Brasilia belt. It has been interpreted as the root of a magmatic arc, possibly connected with the Rio de la Plata/ Paraná craton. The southeastern boundary of the Cunha de Guaxupè was reworked by ductile wrench faults belonging to the Ribeira belt [30].

West of $49^{\circ} \mathrm{W}$, the Ribeira and Brasilia belts are buried under the Paraná basin, which represents an intracontinental large igneous province resulting from the upwelling of the Tristan da Cunha plume at ca. 135 Myr. Recent tomographic models performed by VanDecar et al. [31] and Schimmel et al. [32] imaged a cylindrical-shaped low-velocity anomaly, extending from 200 to at least $600 \mathrm{~km}$ deep beneath the Paraná basin. This low-velocity anomaly was interpreted as the fossil conduit of the Tristan da Cunha plume. As the continent has migrated more than $3000 \mathrm{~km}$ westward since the opening of the South Atlantic ocean, VanDecar et al. [31] proposed that the South American continental lithosphere and the underlying upper mantle moved coherently since the Atlantic opening.

\section{Data acquisition and processing}

Three-component intermediate- and broadband portable stations from the Institute of Astronomy and Geophysics (São Paulo, Brazil), and from the French lithoscope and broad-band networks were deployed at 39 sites from the Paraná basin to the coastal Ribeira belt, and northward to Brasilia (Fig. 2). This experiment was designed 
Table 2

Station information and averaged splitting results (M.E.P. $=$ multiple-event parameters)

\begin{tabular}{|c|c|c|c|c|c|c|c|c|c|c|}
\hline \multirow[t]{2}{*}{ Station } & & \multirow[t]{2}{*}{ Event } & \multirow[t]{2}{*}{$\phi\left({ }^{\circ}\right)$} & \multirow[t]{2}{*}{ Error $\left(^{\circ}\right)$} & \multirow[t]{2}{*}{$\mathrm{d} t(\mathrm{~s})$} & \multirow[t]{2}{*}{ Error (s) } & \multirow[t]{2}{*}{ Phase } & \multirow[t]{2}{*}{ Quality } & \multicolumn{2}{|l|}{ M.E.P. } \\
\hline & & & & & & & & & $\begin{array}{l}\phi\left(^{\circ}\right) \\
\text { Error }\left( \pm^{\circ}\right)\end{array}$ & $\begin{array}{l}\mathrm{d} t(\mathrm{~s}) \\
\text { Error }( \pm \mathrm{s})\end{array}$ \\
\hline ALP & & 39 & 81 & 6 & 2.016 & 0.352 & SKKS & G & 72 & 3 \\
\hline Lat. $\left({ }^{\circ}\right)$ & -21.880 & 39 & 63 & 3 & 2.528 & 0.416 & SKS & G & 1.92 & 0.18 \\
\hline Long. $\left({ }^{\circ}\right)$ & -42.664 & 56 & 67 & 4.5 & 1.664 & 0.192 & SKKS & G & & \\
\hline AREB & & 14 & -72 & 22.5 & 0.5 & 2.225 & SKS & $\mathrm{GN}$ & & \\
\hline Lat. $\left({ }^{\circ}\right)$ & -21.362 & 14 & -67 & 6 & 1.35 & 0.275 & SKKS & $\mathrm{G}$ & & \\
\hline \multirow[t]{24}{*}{ Long. $\left({ }^{\circ}\right)$} & -46.123 & 15 & -27 & 4 & 4 & 0.375 & SKS & G & & \\
\hline & & 16 & -47 & 8.5 & 1.7 & 0.725 & SKS & G & & \\
\hline & & 16 & -52 & 6.5 & 2.1 & 0.6 & SKKS & G & & \\
\hline & & 17 & 56 & 22.5 & 0.35 & 2.15 & PKS & $\mathrm{GN}$ & & \\
\hline & & 18 & -40 & 22.5 & 2.4 & 3.175 & SKKS & $\mathrm{FN}$ & & \\
\hline & & 19 & -42 & 22.5 & 1.5 & 2.725 & SKKS & FN & & \\
\hline & & 20 & 23 & 2.5 & 4 & 3.975 & SKKS & GN & & \\
\hline & & 21 & 41 & 22.5 & 2.5 & 3.225 & SKS & $\mathrm{GN}$ & & \\
\hline & & 22 & -37 & 22.5 & 4 & 4.025 & SKKS & GN & & \\
\hline & & 23 & 16 & 22.5 & 1.75 & 2.85 & SKS & FN & & \\
\hline & & 24 & -40 & 5.5 & 2.8 & 3.425 & SKS & GN & & \\
\hline & & 24 & -43 & 22.5 & 0.95 & 2.5 & SKKS & GN & & \\
\hline & & 25 & -48 & 22.5 & 1.35 & 2.65 & SKS & GN & & \\
\hline & & 25 & -52 & 22.5 & 1.25 & 1.25 & SKKS & $\mathrm{FN}$ & & \\
\hline & & 28 & -47 & 22.5 & 1.45 & 1.225 & PKS & GN & & \\
\hline & & 31 & -44 & 5.5 & 1.55 & 0.55 & SKS & GN & & \\
\hline & & 31 & -45 & 22.5 & 1.4 & 2.675 & SKKS & $\mathrm{FN}$ & & \\
\hline & & 32 & 9 & 22.5 & 1.4 & 2.675 & SKKS & $\mathrm{FN}$ & & \\
\hline & & 35 & -59 & 22.5 & 0.55 & 1.325 & PKS & GN & & \\
\hline & & 36 & -58 & 22.5 & 0.5 & 0.75 & PKS & GN & & \\
\hline & & 37 & -74 & 22.5 & 0.45 & 2.2 & SKKS & $\mathrm{FN}$ & & \\
\hline & & 39 & -43 & 22.5 & 2.15 & 3.05 & SKS & $\mathrm{FN}$ & & \\
\hline & & 40 & -52 & 22.5 & 2.3 & 3.175 & SKKS & $\mathrm{FN}$ & & \\
\hline & & 40 & -55 & 6 & 2.3 & 3.125 & SKS & $\mathrm{FN}$ & & \\
\hline ATDB & & 2 & -75 & 22.5 & 0.85 & 1.95 & SKKS & FN & 157 & 0.80 \\
\hline Lat. $\left({ }^{\circ}\right)$ & -21.290 & 6 & -54 & 8 & 1.65 & 0.625 & SKS & $\mathrm{F}$ & & \\
\hline \multirow[t]{6}{*}{ Long. $\left(^{\circ}\right)$} & -42.861 & 9 & -13 & 3.5 & 2.45 & 0.7 & SKKS & G & & \\
\hline & & 11 & -32 & 22.5 & 1.8 & 1.35 & SKKS & FN & & \\
\hline & & 12 & -80 & 22 & 0.75 & 1.65 & SKKS & FN & & \\
\hline & & 67 & -81 & 22.5 & 0.875 & 2.188 & SKS & $\mathrm{FN}$ & & \\
\hline & & 68 & -74 & 14.5 & 0.575 & 0.163 & SKS & $\mathrm{G}$ & & \\
\hline & & 68 & -78 & 8 & 1.125 & 0.15 & SKKS & G & & \\
\hline BARB & & 25 & -73 & 21.5 & 0.75 & 0.425 & SKS & $\mathrm{F}$ & & \\
\hline Lat. $\left(^{\circ}\right)$ & -21.221 & 25 & 61 & 7 & 1.6 & 0.525 & SKKS & G & & \\
\hline Long. $\left({ }^{\circ}\right)$ & -43.800 & 26 & 66 & 16 & 1.85 & 0.8 & SKKS & $\mathrm{F}$ & & \\
\hline & & 42 & -60 & 22.5 & 1.1 & 1.75 & SKKS & $\mathrm{F}$ & & \\
\hline & & 46 & -81 & 13 & 0.8 & 0.2 & SKKS & G & & \\
\hline & & 51 & -63 & 2.5 & 1.5 & 0.15 & SKS & G & & \\
\hline & & 52 & -69 & 6.5 & 1.1 & 0.225 & SKKS & G & & \\
\hline & & 56 & 36 & 13 & 0.95 & 0.375 & SKKS & $\mathrm{G}$ & & \\
\hline BRSB & & 5 & -37 & 22.5 & 3.2 & 3.625 & SKS & FN & 82 & 0.80 \\
\hline Lat. $\left(^{\circ}\right)$ & -22.535 & 7 & -37 & 22.5 & 3.2 & 3.625 & SKS & $\mathrm{FN}$ & 5.5 & 0.1 \\
\hline Long. $\left({ }^{\circ}\right)$ & -45.585 & 7 & 56 & 22.5 & 0.9 & 2.475 & SKKS & $\mathrm{FN}$ & & \\
\hline & & 7 & -83 & 17 & 1.2 & 0.475 & SKS & $\mathrm{F}$ & & \\
\hline & & 10 & 67 & 22.5 & 1.4 & 2.675 & SKS & FN & & \\
\hline & & 14 & 65 & 3.5 & 0.95 & 0.15 & SKS & $\mathrm{G}$ & & \\
\hline & & 14 & 80 & 16.5 & 1.15 & 0.4 & SKKS & G & & \\
\hline & & 16 & 87 & 16.5 & 0.75 & 0.25 & SKS & G & & \\
\hline & & 16 & -81 & 19.5 & 0.6 & 0.45 & SKKS & $\mathrm{F}$ & & \\
\hline & & 25 & -65 & 10 & 1.25 & 0.375 & SKKS & G & & \\
\hline & & 25 & -66 & 12.5 & 1.2 & 0.325 & SKS & $\mathrm{F}$ & & \\
\hline BSCB & & 25 & -55 & 22.5 & 0.65 & 2.35 & SKS & $\mathrm{F}$ & -57 & 1.05 \\
\hline Lat. $\left({ }^{\circ}\right)$ & -20.999 & 25 & -56 & 3.5 & 1.55 & 0.275 & SKKS & $\mathrm{G}$ & 2.5 & 0.13 \\
\hline Long. $\left({ }^{\circ}\right)$ & -44.764 & 30 & -44 & 22.5 & 2.3 & 3.175 & SKS & $\mathrm{FN}$ & & \\
\hline & & 30 & -67 & 17.5 & 1 & 0.425 & SKKS & $\mathrm{F}$ & & \\
\hline & & 31 & -55 & 5 & 1.1 & 0.2 & SKS & G & & \\
\hline & & 31 & -55 & 10.5 & 1.2 & 0.375 & SKKS & G & & \\
\hline & & 33 & -44 & 2.5 & 3.75 & 3.9 & SKS & FN & & \\
\hline
\end{tabular}


Table 2 (Continued).

\begin{tabular}{|c|c|c|c|c|c|c|c|c|c|c|}
\hline \multirow[t]{2}{*}{ Station } & & \multirow[t]{2}{*}{ Event } & \multirow[t]{2}{*}{$\phi\left({ }^{\circ}\right)$} & \multirow[t]{2}{*}{ Error $\left({ }^{\circ}\right)$} & \multirow[t]{2}{*}{$\mathrm{d} t(\mathrm{~s})$} & \multirow[t]{2}{*}{ Error (s) } & \multirow[t]{2}{*}{ Phase } & \multirow[t]{2}{*}{ Quality } & \multicolumn{2}{|l|}{ M.E.P. } \\
\hline & & & & & & & & & $\begin{array}{l}\phi\left(^{\circ}\right) \\
\text { Error }\left( \pm^{\circ}\right)\end{array}$ & $\begin{array}{l}\mathrm{d} t(\mathrm{~s}) \\
\text { Error }( \pm \mathrm{s})\end{array}$ \\
\hline & & 33 & -45 & 2.5 & 4 & 1.4 & SKKS & FN & & \\
\hline & & 35 & -79 & 19.5 & 0.55 & 0.275 & PKS & $\mathrm{G}$ & & \\
\hline & & 36 & -44 & 2 & 1.65 & 0.45 & SKKS & G & & \\
\hline & & 39 & -63 & 6 & 1 & 0.18 & SKKS & $\mathrm{F}$ & & \\
\hline & & 39 & -69 & 22.5 & 0.5 & 0.825 & SKS & $\mathrm{F}$ & & \\
\hline & & 40 & -53 & 2 & 3.5 & 3.335 & SKS & $\mathrm{F}$ & & \\
\hline & & 40 & -55 & 22.5 & 2.5 & 3.275 & SKKS & $\mathrm{FN}$ & & \\
\hline & & 42 & -77 & 22.5 & 0.95 & 0.95 & SKKS & FN & & \\
\hline CAMB & & 38 & 23 & 2 & 4 & 0.5 & SKKS & $\mathrm{FN}$ & -55 & 0.85 \\
\hline Lat. $\left({ }^{\circ}\right)$ & -21.784 & 39 & 52 & 22.5 & 2.4 & 1.95 & SKS & $\mathrm{FN}$ & 7.5 & 0.23 \\
\hline \multirow[t]{4}{*}{ Long. $\left({ }^{\circ}\right)$} & -41.429 & 39 & 89 & 11.5 & 0.5 & 0.125 & SKKS & $\mathrm{G}$ & & \\
\hline & & 40 & 46 & 4 & 2.25 & 3.15 & SKS & $\mathrm{F}$ & & \\
\hline & & 40 & 51 & 22.5 & 1.25 & 2.65 & SKKS & $\mathrm{FN}$ & & \\
\hline & & 42 & 85 & 19.5 & 0.9 & 0.525 & SKKS & $\mathrm{F}$ & & \\
\hline CRG & & 40 & -42 & 2 & 4 & 0.336 & SKS & GN & & \\
\hline Lat. $\left({ }^{\circ}\right)$ & -20.750 & 40 & 51 & 22.5 & 0.384 & 2.208 & SKKS & GN & & \\
\hline \multirow[t]{13}{*}{ Long. $\left({ }^{\circ}\right)$} & -42.000 & 41 & -33 & 6 & 2.272 & 3.12 & SKS & $\mathrm{FN}$ & & \\
\hline & & 42 & -76 & 22.5 & 0.608 & 0.608 & SKKS & $\mathrm{FN}$ & & \\
\hline & & 43 & 43 & 22.5 & 0.768 & 2.4 & SKKS & FN & & \\
\hline & & 45 & -47 & 1.5 & 2.176 & 0.176 & SKKS & FN & & \\
\hline & & 50 & -27 & 22.5 & 0.8 & 0.608 & SKKS & FN & & \\
\hline & & 54 & -76 & 1 & 1.504 & 0.176 & SKS & GN & & \\
\hline & & 55 & 47 & 1.5 & 4 & 3.984 & SKS & $\mathrm{FN}$ & & \\
\hline & & 56 & -73 & 22.5 & 2.112 & 3.04 & SKKS & $\mathrm{N}$ & & \\
\hline & & 57 & -28 & 5 & 1.312 & 0.224 & SKKS & $\mathrm{F}$ & & \\
\hline & & 58 & -29 & 0.5 & 2.56 & 0.288 & SKS & $\mathrm{FN}$ & & \\
\hline & & 58 & -25 & 2 & 3.552 & 0.464 & SKKS & FN & & \\
\hline & & 59 & 68 & 4 & 0.992 & 0.176 & SKS & GN & & \\
\hline & & 59 & -50 & 3.5 & 1.312 & 0.336 & SKKS & G & & \\
\hline FRMB & & & & & & & & & 124 & 0.95 \\
\hline Lat. $\left(^{\circ}\right)$ & -20.488 & & & & & & & & 7 & 0.28 \\
\hline Long. $\left({ }^{\circ}\right)$ & -45.642 & & & & & & & & & \\
\hline FURB & & & & & & & & & 126 & 0.85 \\
\hline Lat. $\left({ }^{\circ}\right)$ & -20.678 & & & & & & & & 12 & 0.4 \\
\hline Long. $\left({ }^{\circ}\right)$ & -46.278 & & & & & & & & & \\
\hline IGAB & & 65 & 54 & 3.5 & 4 & 0.575 & SKS & $\mathrm{F}$ & 71 & 2.4 \\
\hline Lat. $\left({ }^{\circ}\right)$ & -23.253 & 37 & 69 & 7.5 & 1.95 & 0.3 & SKKS & G & 3 & 0.3 \\
\hline Long. $\left({ }^{\circ}\right)$ & -46.117 & 39 & 67 & 1.5 & 3.55 & 0.25 & SKS & G & & \\
\hline & & 39 & 70 & 3 & 3.4 & 0.45 & SKKS & G & & \\
\hline & & 42 & 64 & 2 & 3.2 & 0.2 & SKKS & $\mathrm{F}$ & & \\
\hline & & 48 & 59 & 3.5 & 4 & 0.625 & SKS & $\mathrm{F}$ & & \\
\hline & & 65 & 74 & 4.5 & 2.5 & 0.3 & SKKS & $\mathrm{F}$ & & \\
\hline & & 68 & 69 & 5 & 3.6 & 0.8 & SKKS & $\mathrm{F}$ & & \\
\hline & & 68 & 65 & 2.5 & 4 & 0.575 & SKS & $\mathrm{F}$ & & \\
\hline JFOB & & 29 & 88 & 16 & 1.15 & 0.4 & SKKS & $\mathrm{F}$ & & \\
\hline Lat. $\left({ }^{\circ}\right)$ & -21.728 & 32 & -71 & 6 & 2.1 & 0.675 & SKKS & $\mathrm{F}$ & & \\
\hline Long. $\left({ }^{\circ}\right)$ & -43.326 & 33 & -50 & 10 & 1.7 & 0.625 & SKS & $\mathrm{FN}$ & & \\
\hline & & 33 & 79 & 18 & 1.2 & 0.475 & SKKS & $\mathrm{F}$ & & \\
\hline & & 36 & 83 & 15.5 & 1.05 & 0.35 & SKKS & $\mathrm{F}$ & & \\
\hline & & 38 & 19 & 2.5 & 2.25 & 0.6 & SKKS & GN & & \\
\hline & & 39 & 62 & 2 & 1.95 & 0.3 & SKS & $\mathrm{G}$ & & \\
\hline & & 39 & 90 & 5 & 0.95 & 0.10 & SKKS & G & & \\
\hline & & 40 & 62 & 1.65 & 1.1 & 0.5 & SKS & $\mathrm{F}$ & & \\
\hline & & 40 & 49 & 6.5 & 1.65 & 0.575 & SKKS & $\mathrm{F}$ & & \\
\hline & & 52 & 63 & 8 & 3.25 & 0.825 & SKKS & $\mathrm{F}$ & & \\
\hline & & 56 & 59 & 10 & 1.25 & 0.225 & SKKS & G & & \\
\hline & & 61 & 70 & 13.5 & 0.95 & 0.375 & SKS & $\mathrm{F}$ & & \\
\hline & & 63 & 78 & 9 & 0.6 & 0.125 & SKS & G & & \\
\hline & & 63 & -83 & 8 & 1.35 & 0.25 & SKKS & $\mathrm{F}$ & & \\
\hline JUQB & & 58 & 82 & 6 & 1.55 & 0.3 & SKS & G & -86 & 0.85 \\
\hline Lat. $\left({ }^{\circ}\right)$ & -24.093 & 58 & -82 & 8 & 1.15 & 0.175 & SKS & G & 2 & 0.05 \\
\hline Long. $\left({ }^{\circ}\right)$ & -47.716 & 63 & 90 & 2.5 & 0.8 & 0.05 & SKS & $\mathrm{G}$ & & \\
\hline & & 64 & -79 & 2 & 0.8 & 0.05 & SKKS & $\mathrm{G}$ & & \\
\hline & & 66 & 77 & 8 & 1.45 & 0.275 & SKS & G & & \\
\hline
\end{tabular}


Table 2 (Continued).

\begin{tabular}{|c|c|c|c|c|c|c|c|c|c|c|}
\hline \multirow[t]{2}{*}{ Station } & & \multirow[t]{2}{*}{ Event } & \multirow[t]{2}{*}{$\phi\left({ }^{\circ}\right)$} & \multirow[t]{2}{*}{ Error $\left({ }^{\circ}\right)$} & \multirow[t]{2}{*}{$\mathrm{d} t(\mathrm{~s})$} & \multirow[t]{2}{*}{ Error (s) } & \multirow[t]{2}{*}{ Phase } & \multirow[t]{2}{*}{ Quality } & \multicolumn{2}{|l|}{ M.E.P. } \\
\hline & & & & & & & & & $\begin{array}{l}\phi\left(^{\circ}\right) \\
\text { Error }\left( \pm^{\circ}\right)\end{array}$ & $\begin{array}{l}\mathrm{d} t(\mathrm{~s}) \\
\text { Error }( \pm \mathrm{s})\end{array}$ \\
\hline & & 68 & 82 & 14 & 1.3 & 0.525 & SKKS & $\mathrm{F}$ & & \\
\hline & & 68 & 85 & 4.5 & 1.4 & 0.225 & SKS & G & & \\
\hline & & 69 & -88 & 8 & 1.25 & 0.20 & SKS & $\mathrm{F}$ & & \\
\hline LJM & & 52 & 79 & 21 & 0.736 & 0.368 & SKS & $\mathrm{F}$ & & \\
\hline Lat. $\left({ }^{\circ}\right)$ & -21.290 & 44 & -68 & 1 & 2.112 & 0.096 & SKS & G & & \\
\hline \multirow[t]{6}{*}{ Long. $\left({ }^{\circ}\right)$} & -42.053 & 47 & 20 & 2.5 & 1.6 & 0.16 & SKKS & G & & \\
\hline & & 49 & 65 & 3 & 2.208 & 0.4 & SKS & G & & \\
\hline & & 58 & -62 & 14 & 0.6 & 0.16 & SKS & G & & \\
\hline & & 58 & 76 & 14 & 0.7 & 0.24 & SKKS & G & & \\
\hline & & 59 & 84 & 5 & 1.1 & 0.16 & SKKS & G & & \\
\hline & & 60 & 79 & 11 & 1.4 & 0.32 & SKKS & $\mathrm{F}$ & & \\
\hline NATB & & 3 & -76 & 15.5 & 0.7 & 0.225 & SKKS & $\mathrm{F}$ & & \\
\hline Lat. $\left({ }^{\circ}\right)$ & -21.055 & 7 & 77 & 17 & 0.45 & 0.3 & SKS & $\mathrm{F}$ & & \\
\hline \multirow[t]{5}{*}{ Long. $\left({ }^{\circ}\right)$} & -42.004 & 7 & 88 & 15 & 1 & 0.4 & SKKS & $\mathrm{F}$ & & \\
\hline & & 9 & -61 & 10 & 1.1 & 0.25 & SKKS & G & & \\
\hline & & 10 & 56 & 22.5 & 2.85 & 3.4 & SKS & $\mathrm{FN}$ & & \\
\hline & & 16 & 67 & 22.5 & 0.75 & 1.1 & SKS & $\mathrm{F}$ & & \\
\hline & & 16 & 85 & 7 & 0.8 & 0.1 & SKKS & G & & \\
\hline RSTB & & 64 & -65 & 3.5 & 0.65 & 0.05 & SKKS & G & -79 & 0.85 \\
\hline Lat. $\left({ }^{\circ}\right)$ & -24.651 & 65 & -57 & 6 & 2.8 & 1 & SKKS & $\mathrm{F}$ & 5 & 0.13 \\
\hline Long. $\left({ }^{\circ}\right)$ & -49.034 & 65 & -84 & 3.5 & 1.15 & 0.075 & SKS & G & & \\
\hline SJM & & & & & & & & & 138 & 2 \\
\hline Lat. $\left({ }^{\circ}\right)$ & -21.931 & & & & & & & & 2 & 0.3 \\
\hline Long. $\left({ }^{\circ}\right)$ & -45.963 & & & & & & & & & \\
\hline SPB & & 8 & -84 & 4.5 & 1.95 & 0.225 & SKS & $\mathrm{F}$ & 86 & 1.45 \\
\hline Lat. $\left({ }^{\circ}\right)$ & -23.592 & 8 & -79 & 9 & 1.35 & 0.275 & SKKS & $\mathrm{F}$ & 1.5 & 0.08 \\
\hline \multirow[t]{14}{*}{ Long. $\left({ }^{\circ}\right)$} & -47.432 & 31 & -82 & 6.5 & 1.45 & 0.2 & SKKS & G & & \\
\hline & & 31 & 89 & 1 & 1.45 & 0.05 & SKS & G & & \\
\hline & & 32 & -84 & 10 & 1.75 & 0.5 & SKKS & $\mathrm{F}$ & & \\
\hline & & 33 & -68 & 11 & 1.7 & 0.45 & SKS & $\mathrm{F}$ & & \\
\hline & & 34 & 81 & 4 & 1.45 & 0.175 & PKS & $\mathrm{F}$ & & \\
\hline & & 35 & 89 & 4 & 1.35 & 0.125 & PKS & G & & \\
\hline & & 36 & -77 & 9 & 1.4 & 0.275 & SKKS & G & & \\
\hline & & 39 & 89 & 5 & 1.35 & 0.15 & SKS & G & & \\
\hline & & 39 & -77 & 3.5 & 1.7 & 0.15 & SKKS & G & & \\
\hline & & 52 & 81 & 21.5 & 1.8 & 1.1 & SKS & $\mathrm{F}$ & & \\
\hline & & 53 & -84 & 4 & 1.7 & 0.35 & SKKS & $\mathrm{F}$ & & \\
\hline & & 62 & -88 & 11 & 1.45 & 0.425 & SKS & $\mathrm{F}$ & & \\
\hline & & 63 & -79 & 4.5 & 1.6 & 0.175 & SKKS & G & & \\
\hline & & 63 & 89 & 5 & 1.15 & 0.15 & SKS & G & & \\
\hline TRRB & & 2 & 69 & 13 & 3.2 & 0.8 & SKKS & $\mathrm{F}$ & 78 & 1.4 \\
\hline Lat. $\left(^{\circ}\right)$ & -22.154 & 4 & 71 & 11.5 & 1.65 & 0.9 & SKKS & $\mathrm{F}$ & 1.5 & 0.1 \\
\hline Long. $\left({ }^{\circ}\right)$ & -43.195 & 5 & 64 & 4 & 3.45 & 0.7 & SKS & G & & \\
\hline & & 7 & 66 & 5 & 1.65 & 0.25 & SKS & G & & \\
\hline & & 7 & 82 & 5 & 2.2 & 0.25 & SKKS & G & & \\
\hline & & 9 & 73 & 22.5 & 0.95 & 0.975 & SKKS & $\mathrm{F}$ & & \\
\hline & & 13 & 81 & 15.5 & 0.85 & 0.35 & SKS & G & & \\
\hline & & 13 & 80 & 7.5 & 1.75 & 0.275 & SKKS & G & & \\
\hline & & 16 & 76 & 10.5 & 1.15 & 0.275 & SKS & G & & \\
\hline & & 16 & 90 & 11.5 & 1.45 & 0.3 & SKKS & $\mathrm{F}$ & & \\
\hline & & 24 & 70 & 2 & 1.9 & 0.225 & SKS & G & & \\
\hline & & 24 & 86 & 20 & 0.95 & 0.475 & SKKS & $\mathrm{F}$ & & \\
\hline & & 27 & 76 & 11 & 1.2 & 0.275 & SKS & $\mathrm{F}$ & & \\
\hline & & 27 & 81 & 10.5 & 1.55 & 0.325 & SKKS & G & & \\
\hline VABB & & 1 & 74 & 4 & 2.2 & 0.4 & SKS & $\mathrm{F}$ & 86 & 1.45 \\
\hline Lat. $\left({ }^{\circ}\right)$ & -23.002 & 1 & -49 & 4 & 2.55 & 0.625 & SKKS & $\mathrm{F}$ & 1.5 & 0.08 \\
\hline Long. $\left({ }^{\circ}\right)$ & -46.966 & 3 & -88 & 7 & 1.35 & 0.3 & SKKS & $\mathrm{F}$ & & \\
\hline & & 9 & 69 & 22.5 & 1.75 & 2.85 & SKS & GN & & \\
\hline & & 14 & -87 & 3 & 1.55 & 0.1 & SKKS & $\mathrm{G}$ & & \\
\hline & & 14 & 75 & 2 & 1.7 & 0.125 & SKS & G & & \\
\hline & & 16 & -85 & 5 & 1.45 & 0.15 & SKKS & G & & \\
\hline & & 16 & 84 & 4.5 & 1.5 & 0.2 & SKS & G & & \\
\hline
\end{tabular}


to test and complement the preliminary results obtained by James and Assumpção [23]. In this paper, we focus on the measurements performed in the Ribeira and southern Brasilia belts.

Sixty-nine events (see Table $1^{2}$ ) at teleseismic distances in the range of $85-150^{\circ}$, with a magnitude $(\mathrm{Mw}) \geq 5.5$, and a good signal-to-noise ratio were selected using the Preliminary Determination of Epicenters from the National Earthquake Information Center. Due to both the location of the study area relative to the seismogenic zones and the event selection parameters, good recordings of core shear waves were only obtained over a rather narrow range of backazimuths (Fig. 3). Most events used for splitting analysis came from Fidji-Tonga-Kermadec and Papoua-New Guinea regions.

Shear wave splitting measurements were made using Silver and Chan's algorithm [33], which consists in minimizing the energy on the transverse component, by rotating and time shifting the traces (e.g. see Fig. $4^{2}$ ). The energy on the transverse component is automatically evaluated for many candidate values of $\phi$ and $\mathrm{d} t$ (increments of $1^{\circ}$ and $0.05 \mathrm{~s}$ respectively) to retrieve the $\phi$ and $\mathrm{d} t$ pair that better removes anisotropy. This method assumes the seismic anisotropy to be homogeneous in a single horizontal layer.

The influence of time windowing and filtering (Butterworth pass-band filter, lower limit $=0.03$ $\mathrm{Hz}$ and upper limit varying from 0.2 to $0.9 \mathrm{~Hz}$, with an increment of $0.1 \mathrm{~Hz}$ ) on the results was systematically checked. Individual measurements are sorted as 'good', 'fair' or 'poor', with respect to the four quality criteria defined by Barruol et al. [24]: (1) quality of the initial signal (signal-tonoise ratio and possible interference with direct S-wave), (2) ellipticity of particle motion in the horizontal plane when anisotropy is present, (3) linearization of particle motion by anisotropy removal, and (4) waveform coherence between the fast and slow split shear waves. Measurements satisfying the four criteria, producing similar pulse shapes and linear particles motion after correction along with fairly small error ellipses, were

\footnotetext{
${ }^{2}$ See the online version of this article.
}

rated as 'good', while those verifying only three criteria were rated as 'fair'. Only 'good' and 'fair' measurements were retained for interpretation.

Silver and Chan's method [33] has been extended by Wolfe and Silver [34] to find the $\phi$ and $\mathrm{d} t$ pair that better removes the anisotropy in a data set composed of several events recorded at a single station. This formulation also assumes a single anisotropic layer, and it is well suited for events azimuthally well distributed, i.e. when the initial polarization of the phases varies. Estimates are usually improved and the 95\% confidence domain significantly reduced. In our case, as backazimuthal coverage is not homogeneous, this method, hereinafter referred to as the 'multipleevent method', was used for stations with relatively homogeneous splitting parameters, to determine an average value of $\phi$ and $\mathrm{d} t$ from 'good' and 'fair' measurements.

\section{Results}

After severe selection based on the teleseismic distance, magnitude, and signal-to-noise ratio, between 1 and 20 measurements per station have been retained (Table 2). Results are summarized in Fig. 5A (individual shear wave splitting measurements) and Fig. 5B (null measurements and results of the multiple-event method).

Splitting parameters display consistent variations along the Ribeira belt and can be sorted into three domains, corresponding to: (1) the northern, thrust-dominated part of the Ribeira belt, (2) the central, wrench fault-dominated domain, and (3) the southernmost part, characterized by a shallower deformation and lower grade metamorphism.

At the transition between the northern and central domains, splitting parameters were retrieved at three stations: CRG, NATB and LJM. At CRG, 15 measurements have been made on 12 events with different backazimuths (between $142.4^{\circ}$ and $234.9^{\circ}$ ) and a good signal-to-noise ratio. None of these measurements show evidence of energy on the transverse component (null measurements; see Fig. $6^{2}$ ). A 'null' measurement may be due either to an absence of anisotropy 


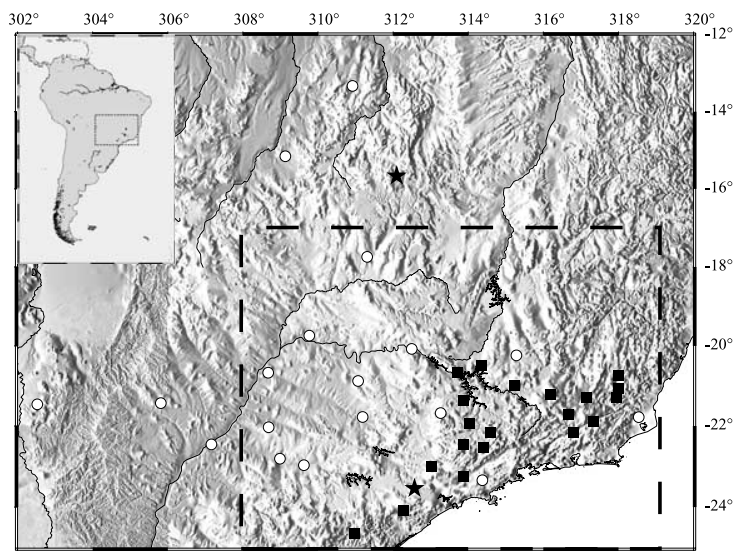

Fig. 2. Location of the 39 instrumented sites. Dashed line= main geological subdivision. Black squares = stations for which results are presented in this paper; the black star represent SPB (São Paulo) permanent GEOSCOPE station to the south, and BDFB (Brasilia) permanent GTSN station to the north.

or to an initial polarization of the incoming shear wave parallel or orthogonal $\left(\mathrm{N} 320^{\circ} \mathrm{E}\right.$ or $\left.\mathrm{N} 050^{\circ} \mathrm{E}\right)$ to the fast anisotropic direction. Considering the backazimuthal coverage of the data used at this station, the results suggest an apparent isotropy.

NATB, LJM, JFOB and BARB display a rather large dispersion of $\phi$ and $\mathrm{d} t$ with two main $\phi$ directions: $\sim$ ENE and $\sim$ WNW, respectively slightly oblique and almost normal to the structural trend. At NATB, for instance, two measurements performed on two distinct events give well-constrained (good to very good) but significantly different results: $\phi=-61 \pm 10^{\circ}$ and $\mathrm{d} t=$ $1.1 \pm 0.25 \mathrm{~s}$ on event 9 (backazimuth $=358.2^{\circ}$ ), and $\phi=85 \pm 7^{\circ}$ and $\mathrm{d} t=0.8 \pm 0.1 \mathrm{~s}$ on event 16 (backazimuth $=228.5^{\circ}$ ). These results might suggest either a dipping anisotropic structure or multiple anisotropic layers. However, the poor backazimuthal coverage impedes further testing of this hypothesis. Considering the complexity of the results at those stations, we avoided computing the average value using the multiple-event method and retained both dominant $\phi$ directions.

In the central Ribeira belt, stations located close to the large-scale dextral wrench faults show polarization directions of the fast split shear wave ranging between $\mathrm{N} 060^{\circ} \mathrm{E}$ and $\mathrm{N} 080^{\circ} \mathrm{E}$. These directions are close to the structural trend of the Ribeira belt $\left(\mathrm{N} 065^{\circ} \mathrm{E}\right)$. They are also close to the direction of the APM as determined using HS3-Nuvel 1A (N253 $\left.{ }^{\circ} \mathrm{E}\right)$ [35] and significantly oblique on the APM determined using Wang and Wang's model (N283 $\left.{ }^{\circ} \mathrm{E}\right)$ [36].

Delay times measured at IGAB and ALP, respectively located on the Igarata and Alem Paraiba wrench faults, are exceptionally large. Individual splitting measurements performed on six events, with similar backazimuth recorded at IGAB, yield values ranging between $1.95 \pm 0.3 \mathrm{~s}$ and $3.55 \pm 0.18 \mathrm{~s}$ (Fig. 7). These values result from high-quality measurements and are regarded as reliable. Measurements have been made on both SKS and SKKS phases for event 39 and show delay time of respectively $3.55 \pm 0.20 \mathrm{~s}$ and $3.40 \pm 0.45 \mathrm{~s}$. This good agreement supports the idea that anisotropy is acquired along the segment of the path below the station that is common to both waves. An average value of $2.40 \pm 0.30 \mathrm{~s}$ has been computed for $\mathrm{d} t$ on four events using the multiple-event method. This seems a reasonable estimate for the anisotropy at IGAB. For the ALP station, the delay time obtained for individual measurements varies between 1.5 and $2.5 \mathrm{~s}$, and an average value of $1.92 \pm 0.18 \mathrm{~s}$ was obtained using two events and three phases.

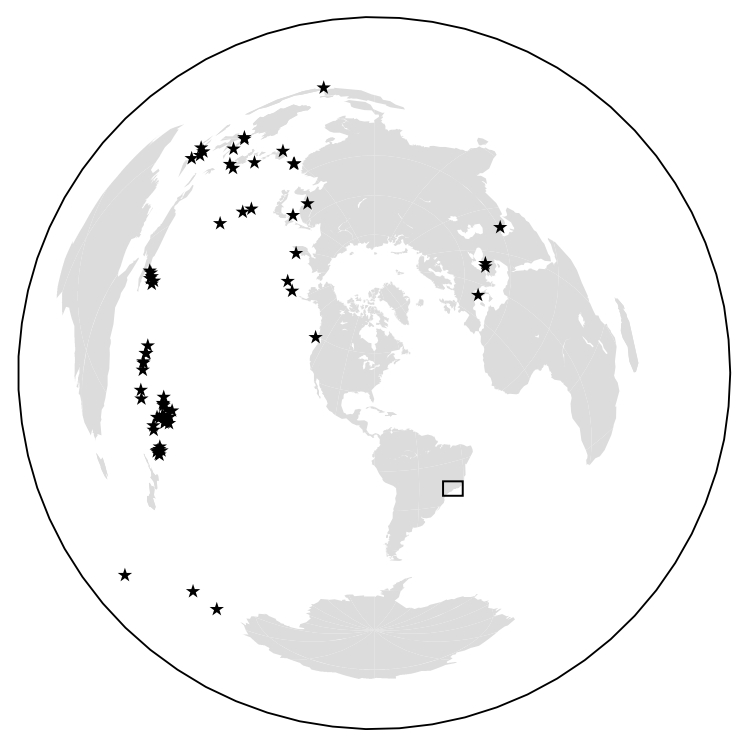

Fig. 3. Distribution of epicenters of events used for this study. 

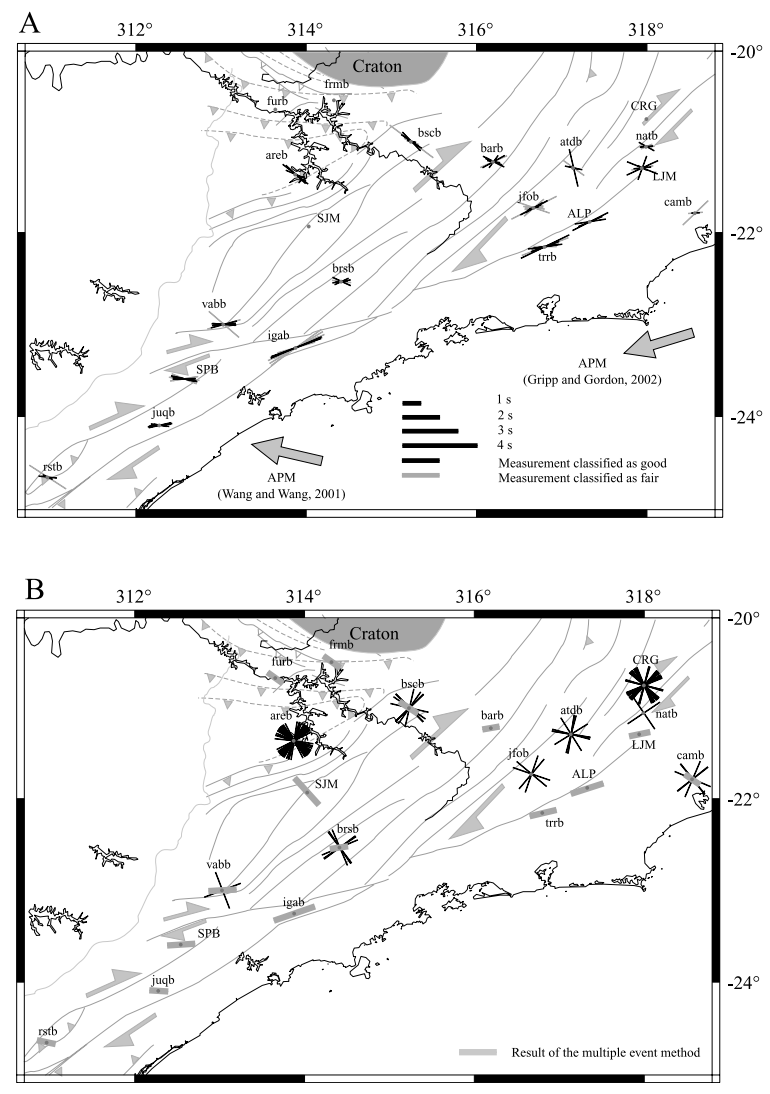

Fig. 5. Measured directions of polarization of the fast split wave. (A) Good (black) and fair (gray) measurements. The length of each line is proportional to the delay time. (B) Null measurements associated with the results of the multipleevent method (gray bold lines, with the lengths of lines proportional to the delay time). Crosses denote absence of splitting. Each branch is either parallel or perpendicular to the backazimuth of the incoming waves and represents a possible direction of anisotropy.

In the southern Ribeira belt, the splitting parameters $\phi$ and $\mathrm{d} t$ retrieved at station JUQB are respectively in the range of $\mathrm{N} 82-101^{\circ} \mathrm{E}$ and 0.8 $1.55 \mathrm{~s}$, and represent a middle term between those obtained at IGAB $\left(\phi \sim \mathrm{N} 54-74^{\circ} \mathrm{E} ; \mathrm{d} t \sim 1.95-3.55\right.$ $\mathrm{s})$, and at $\mathrm{RSTB}\left(\phi \sim \mathrm{N} 96-123^{\circ} \mathrm{E} ; \mathrm{d} t \sim 0.65-2.8\right.$ s). Splitting parameters retrieved at the GEOSCOPE station SPB are in the range of N81$112^{\circ} \mathrm{E}$ for $\phi$ and $1.15-1.95 \mathrm{~s}$ for $\mathrm{d} t$. An average value of $\phi=86 \pm 1.5^{\circ}$ and $\mathrm{d} t=1.45 \pm 0.08 \mathrm{~s}$ was computed using seven good-quality events. The $\phi$ directions retrieved at those stations suggest a rotation of the polarization plane of the fast split wave between the central and southern parts of the Ribeira belt.

In the southern Brasilia belt, measurements performed at FURB, FRMB [23] and BSCB are characterized by consistent $\phi$ and $\mathrm{d} t$ values. The polarization plane of the fast split shear waves trends $\sim \mathrm{N} 125^{\circ} \mathrm{E}$, i.e. parallel to the tectonic grain of the belt. The delay times measured are around $1.0 \mathrm{~s}$.

A sharp change in the direction of the polarization plane of the fast S-wave occurs between the Ribeira and Brasilia belts (Fig. 8). Measurements performed for the same event (39) at two stations, located in the Ribeira (JFOB) and Brasilia belts (BSCB) (Fig. 8) give $\phi=90 \pm 5^{\circ}$ at JFOB and $-63 \pm 6^{\circ}$ at BSCB. This difference is therefore not due to the use of different subsets of data and reflects short wavelength variations in the upper mantle structure.

In the Cunha de Guaxupè, south of the Brasilia belt, a single measurement performed at SJM gives $\phi=\mathrm{N} 138^{\circ} \mathrm{E} \pm 2^{\circ}$ and $\mathrm{d} t=2.0 \pm 0.3 \mathrm{~s}$. AREB reaches a null result (possible directions of anisotropy: $\mathrm{N} 320^{\circ} \mathrm{E}$ or $\mathrm{N} 050^{\circ} \mathrm{E}$ ) in agreement with measurements at SJM, FURB, FRMB and BSCB. Although only few measurements were performed at SJM and AREB, the good consistency with the results obtained at the stations in the southern Brasilia belt suggests a similar mantle structure beneath both the southern Brasilia belt and the Guaxupè allochton.

Measurements performed at CAMB, close to the Atlantic coast, yield $\phi$ ranging from $46^{\circ}$ to $89^{\circ}$, with two values near east-west and low $\mathrm{d} t$ $(0.5-0.9 \mathrm{~s})$. The low $\mathrm{d} t$ that characterizes this station might suggest that the orogenic lithosphere was affected by the Atlantic rifting.

As far as possible, for each event measurements were made on both SKS and SKKS phases. In most cases, similar splitting parameters were retrieved for the two phases. For a few events, however, the splitting parameters retrieved from the SKS and SKKS phases display a significant discrepancy (see Fig. $9^{2}$ ). For event 63 recorded at JFOB, both phases are characterized by a good signal-to-noise ratio. Measurements using the SKS phase (see Fig. $9 \mathrm{~A}^{2}$ ) yield $\phi=78 \pm 9^{\circ}$, and $\mathrm{d} t=0.6 \pm 0.1 \mathrm{~s}$, whereas for the SKKS phase (see 
Fig. 9B $\left.{ }^{2}\right) \phi=97 \pm 8^{\circ}$ and $\mathrm{d} t=1.35 \pm 0.25 \mathrm{~s}$. Both measurements are of good quality and appear as equally reliable. The source of this discrepancy should be either that different anisotropies have been recorded by both waves along the segments of their ray paths that are not common or that the difference in incidence angle for SKS and SKKS beneath the stations results in sampling an apparently different anisotropy. This latter case is especially expected for the dipping mantle fabric.

\section{Discussion}

Because the relationships between seismic anisotropy and the development of LPO of minerals in upper mantle rocks are quite straightforward, shear wave splitting may be interpreted in terms of tectonic fabric within the upper mantle. The poor vertical resolution of shear wave splitting techniques, however, requires discussing whether a lithospheric or an asthenospheric source, or a combination of both, may account for the observed anisotropy.

\subsection{Asthenospheric origin of the anisotropy}

Simple asthenospheric flow due to the decoupling between a 'flat' lithospheric plate and the underlying mantle [11] would result in splitting parameters coherent in both $\phi$ and $\mathrm{d} t$ over geological domains that differ in both age and structure. APM determined for southeastern Brazil trends $\mathrm{N} 253^{\circ} \mathrm{E}$ using the HS3-Nuvel 1A model [35], a direction close to the structural trend of the Ribeira belt $\left(\mathrm{N} 065^{\circ} \mathrm{E}\right)$, and $\mathrm{N} 283^{\circ} \mathrm{E}$ using the T22A model [36]. An asthenospheric origin of the anisotropy could thus account for the pattern of anisotropy in the Ribeira belt. But short spatial-scale variations of splitting parameters observed over the entire region, especially between the southern Brasilia and Ribeira belts (Fig. 8), does not favor a model of simple asthenospheric flow.

Recent surface [19,37,38] and body [39] wave tomographic models have shown that the São Francisco craton has a thicker lithosphere than the surrounding domains. This topography of the lithosphere-asthenosphere boundary might deflect the asthenospheric flow [20]. This model was suggested by Barruol et al. [24] as a possible explanation for shear wave splitting observations in the eastern United States. As in southeastern Brazil, the APM in the eastern United States is roughly parallel to orogenic belts (the Grenville and Appalachians belts) that bound the North American craton. Although a lithospheric source for seismic anisotropy is likely, especially considering the short wavelength variations in splitting parameters, a contribution from the asthenospheric mantle flowing around the cratonic root cannot be ruled out. Fouch et al. [40] have modeled the asthenospheric flow around a cylindrical cratonic keel including a divot to better reproduce the shape of the North American craton as revealed by tomographic studies [41]. From the modeled flow field, they suggested that anisotropy generated in the subcontinental upper mantle is deflected around cratonic keels and that variations in the directions of the polarization plane of the fast split shear waves may occur over short distances where the boundary of the cratonic keel displays reentrants and promontories.

The Fouch et al's [40] model is, however, not directly transposable to SE Brazil. In contrast with the modeled stiff domain, the São Francisco craton has a NS elongated shape. The APM determined using the HS3-Nuvel 1A model [35] is $\mathrm{N} 253^{\circ} \mathrm{E}$ and thus oblique with respect to the long axis of the craton.

Considering this situation, an asthenospheric flow may be expected at the southeastern tip of the craton that parallels the structural trend of the Ribeira belt, and thus, might explain the observed anisotropy. This model, however, fails to explain the anisotropy pattern in the southernmost Brasilia belt, since this would require a sharp curvature of the flow direction, hardly compatible with mantle rheology [42]. Wang and Wang's [36] model suggests a South American APM $\mathrm{N} 283^{\circ} \mathrm{E}$. Considering this value, a deflected asthenospheric flow around the southern tip of the craton might explain the pattern of anisotropy in the southernmost Brasilia belt, but not within the Ribeira belt. Moreover, asthenospheric flow alone fails to explain short-scale $\mathrm{d} t$ variations 

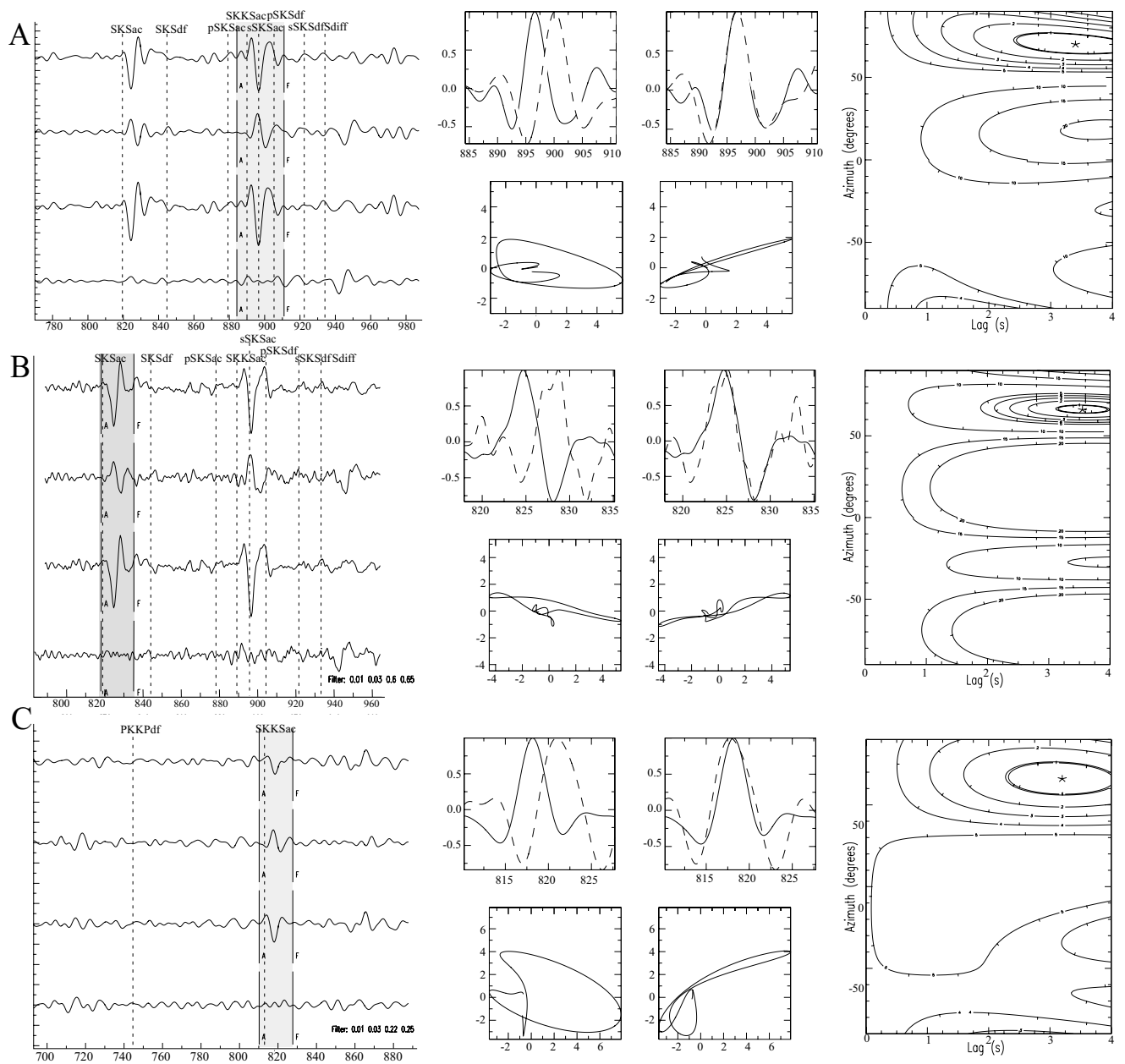

Fig. 7. Examples of splitting measurements at station IGAB. (A) Event 39 (see Table $1^{2}$ : azimuth $=129.7^{\circ}$, backazimuth $\left.=231.2^{\circ}\right): \phi=70 \pm 3^{\circ}$, and $\mathrm{d} t=3.4 \pm 0.45 \mathrm{~s}$, on phase SKKS. (B) Event 39 (see Table $1^{2}:$ azimuth $=129.7^{\circ}$, backazimuth $=231.2^{\circ}$ ): $\phi=67 \pm 1.5^{\circ}$, and $\mathrm{d} t=3.55 \pm 0.25 \mathrm{~s}$, on phase SKS. (C) Event 42 (see Table $1^{2}$ : azimuth $=150.2^{\circ}$, backazimuth $\left.=212.6^{\circ}\right): \phi=64 \pm 2^{\circ}$, and $\mathrm{d} t=3.2 \pm 0.20 \mathrm{~s}$.

and large $\mathrm{d} t$ values recorded at stations located above the lithospheric-scale shear zones within the Ribeira belt.

\subsection{Lithospheric origin of the anisotropy}

There is a conspicuous correlation between the orientation of the fast split shear wave polarization plane and the structural trend of both the Brasilia and Ribeira belts, respectively trending $\mathrm{N} 125^{\circ} \mathrm{E}$ and $\mathrm{N} 065^{\circ} \mathrm{E}$. This correlation may be regarded as a reliable evidence that shear wave splitting results from anisotropy frozen within the lithosphere since the last orogenic event (Neoproterozoic orogeny, ca. $600 \mathrm{Myr}$ ). In the Ribeira belt, this agreement is particularly good for stations close to the major wrench fault, but an obliquity with the structural trend is observed in the northern and southern domains. This discrepancy may result either from variations in the tectonic fabric frozen within the lithospheric mantle (thrust-type in the northern and southern domains, wrench fault-type in the central domain) or from a combination of anisotropies from various sources (lithospheric vs. asthenospheric) variable along-strike. 

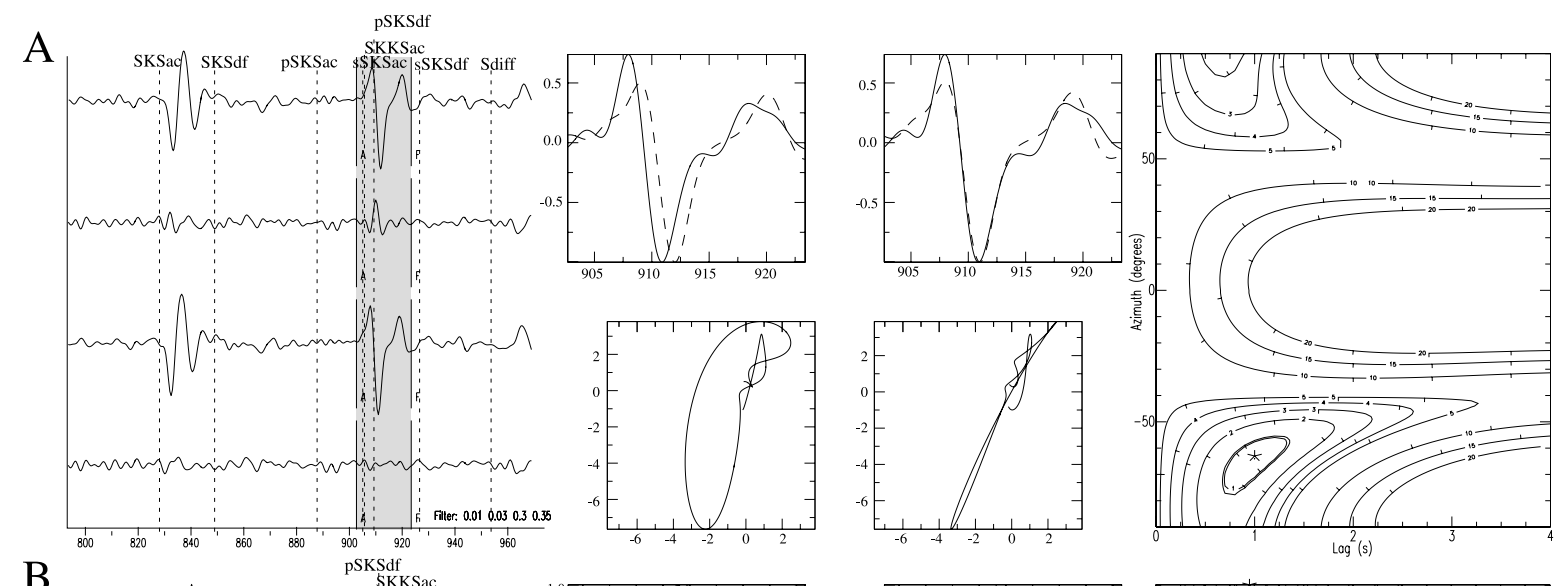

$\mathrm{B}$
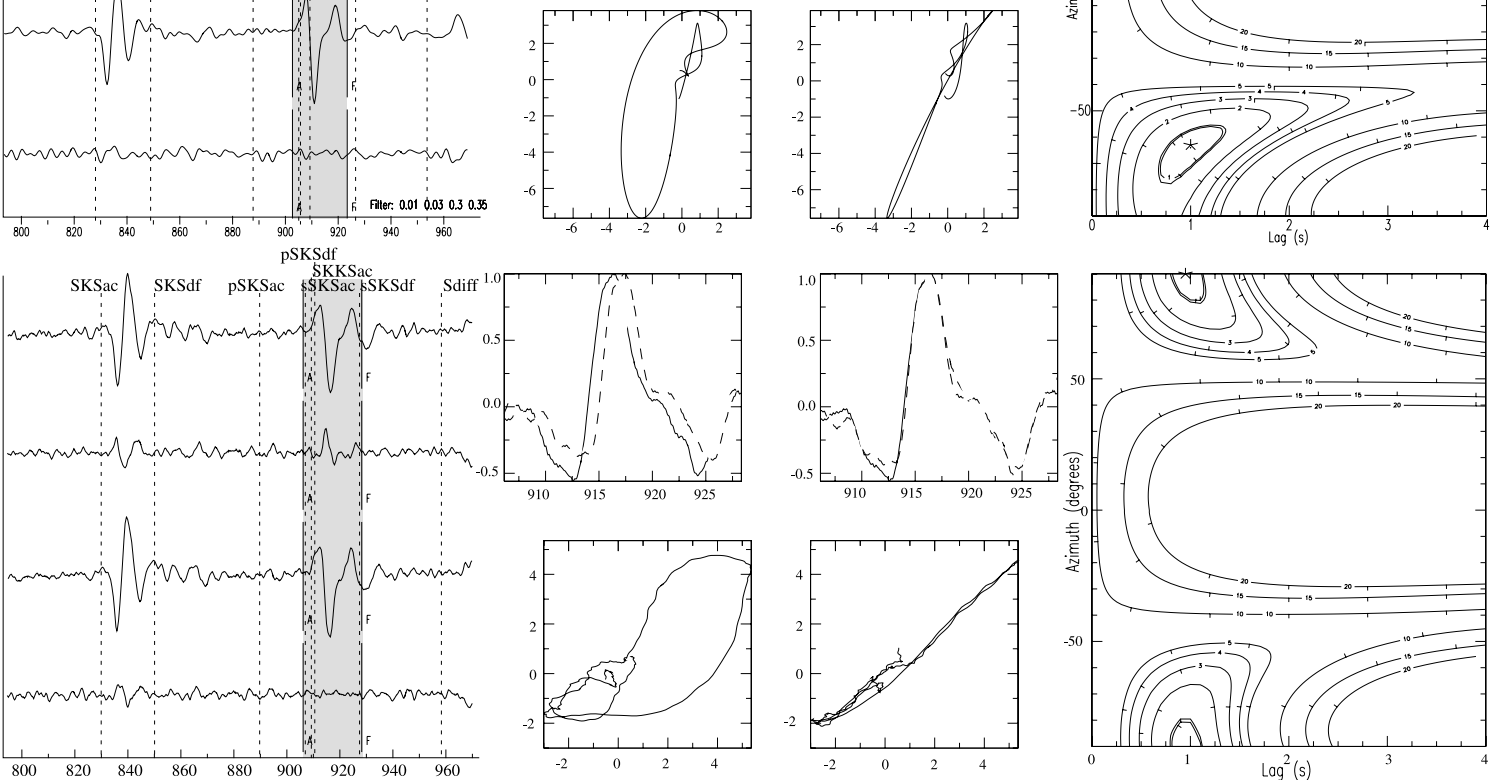

Fig. 8. Shear wave splitting measurements performed on the same event (event 39, see Table $1^{2}$ ) recorded at BSCB and JFOB respectively located in the Brasilia and Ribeira belts. (A) Station BSCB (azimuth $=128.7^{\circ}$, backazimuth $=231.2^{\circ}$ ): $\phi=-63 \pm 6^{\circ}$ and $\mathrm{d} t=1.00 \pm 0.18 \mathrm{~s}$. (B) Station JFOB (azimuth $=130.2^{\circ}$, backazimuth $=229.9^{\circ}$ ): $\phi=90 \pm 5^{\circ}$ and $\mathrm{d} t=0.95 \pm 0.10 \mathrm{~s}$.

Delay times usually observed in southeastern Brazil are close to the worldwide average of $1 \mathrm{~s}$ [1]. However, two stations located above the lithospheric-scale strike-slip faults yield $\mathrm{d} t$ among the largest ever observed. Average $\mathrm{d} t$ retrieved at ALP, located on the Alem Paraiba fault, and at IGAB, located on the Igarata fault, are respectively $1.92 \pm 0.18 \mathrm{~s}$ and $2.40 \pm 0.30 \mathrm{~s}$. Interpretation of such high delay times requires either a much larger intrinsic anisotropy of mantle rocks than commonly described in petrophysical studies, or an anisotropic layer thicker than the lithosphere. Crustal anisotropy may account for delay times up to $0.2-0.3 \mathrm{~s}[15,16]$, consistent with values predicted from rock physics [16]. According to Barruol and Mainprice [17], maximum delay times up to $0.2 \mathrm{~s}$ per $10 \mathrm{~km}$ of pervasively struc- tured crust might be expected. Major wrench faults in the Ribeira belt are marked by wide (up to $10 \mathrm{~km}$ ) mylonitic structures with pervasive vertical foliations and subhorizontal lineations [8]. Assuming these faults crosscut the entire crust, the maximum crustal contribution to splitting would be $\sim 0.6 \mathrm{~s}$. Then, a delay time of $1.8 \mathrm{~s}$ has to be generated in the upper mantle.

Tomographic models [19] suggest a normal lithosphere thickness $(\sim 100 \mathrm{~km})$ beneath the belts surrounding the São Francisco craton. Estimates of shear wave anisotropy for continental lithospheric mantle rocks usually range from $3 \%$ to $10 \%$ for waves propagating in a direction nearly normal to the lineation in the foliation plane $[18,26]$. Assuming a seismic anisotropy of $5 \%$, a value regarded as reasonable for a 'normal' upper 
mantle, the anisotropic layer would be $170 \mathrm{~km}$ thick to explain a delay time of $1.8 \mathrm{~s}$, i.e. a thickness that exceeds the lithosphere thickness and would suggest a sublithospheric contribution. Then, two interpretations are possible: either the frozen fabric in the lithosphere and the APM-related fabric in the asthenosphere are close enough to mimic a single anisotropic layer, or the lithospheric and asthenospheric fabrics result from a single event, and no decoupling occurred between the lithosphere and the asthenosphere since Neoproterozoic times. Considering that the HS3-Nuvel $1 \mathrm{~A}$ APM is close to the structural trend of the Ribeira belt, the first hypothesis is favored. On the other hand, body waves tomography of southeastern Brazil [31,32] imaged a cylindrical low-velocity anomaly extending beneath the Paraná large igneous province from 200 to at least 600 $\mathrm{km}$. This anomaly, interpreted as the fossil signature of the Tristan da Cunha plume, is regarded as a strong argument supporting a coherent motion of the whole upper mantle since at least 130 Myr [31]. Coupling of the lithospheric and sublithospheric mantle would result in an absence of sublithospheric deformation due to current day plate motion.

Assuming the seismic anisotropy entirely generated into the lithosphere, an average S-wave seismic anisotropy of $11 \%$ would be required to generate $\mathrm{d} t$ in the range $1.5-2 \mathrm{~s}$ in a $70-80-\mathrm{km}$-thick lithospheric mantle. Although these values are quite large compared with the $5 \%$ considered previously, they are still realistic. Ben Ismail and Mainprice [5] have reported S-wave anisotropies larger than $10 \%$ and up to $15 \%$. These values were, however, calculated for pure olivine aggregates and should be slightly reduced to take into account the effect of $20-30 \%$ of pyroxenes

Fig. 10. Apparent $\phi(\mathrm{A}, \mathrm{C})$ and $\mathrm{d} t(\mathrm{~B}, \mathrm{D})$ vs. backazimuth of the incoming wave at station TRRB, modeled using two layers of anisotropy with the values of $\phi_{2}$ and $\mathrm{d} t_{2}$ in the bottom layer representing: (A) the direction of APM determined using the HS3-Nuvel $1 \mathrm{~A}$ model, $\mathrm{N} 253^{\circ} \mathrm{E}$ [33] and $0.8 \mathrm{~s}$; (B) the direction of APM determined using the T22A model [34] and $0.8 \mathrm{~s}$. In both models, the fast $\mathrm{S}$-wave polarization in the upper layer is parallel to the structural trend of the $\mathrm{Ri}$ beira belt $\left(\phi_{1}=65^{\circ}, \mathrm{d} t_{1}=1 \mathrm{~s}\right)$.

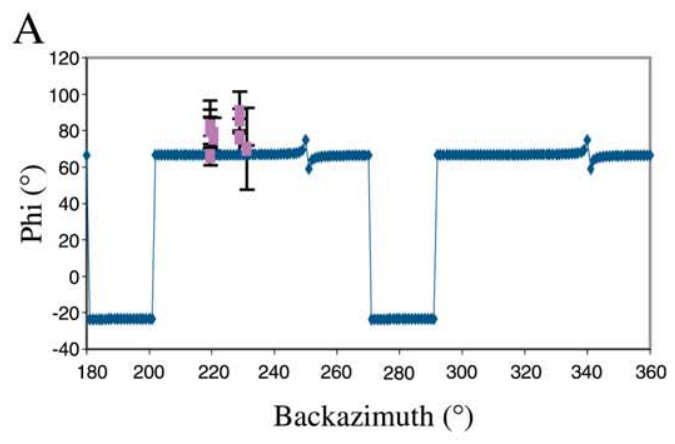

B

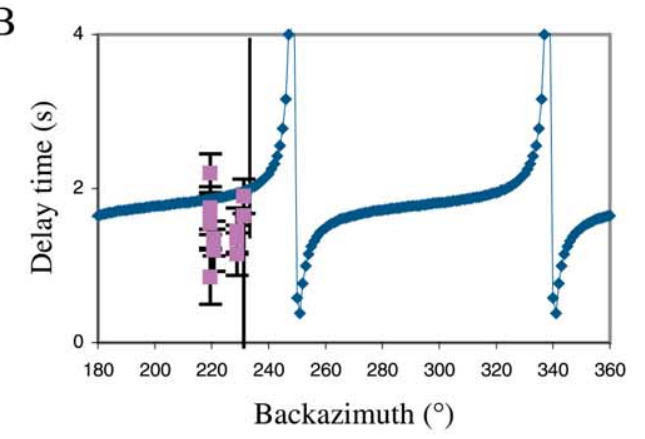

C

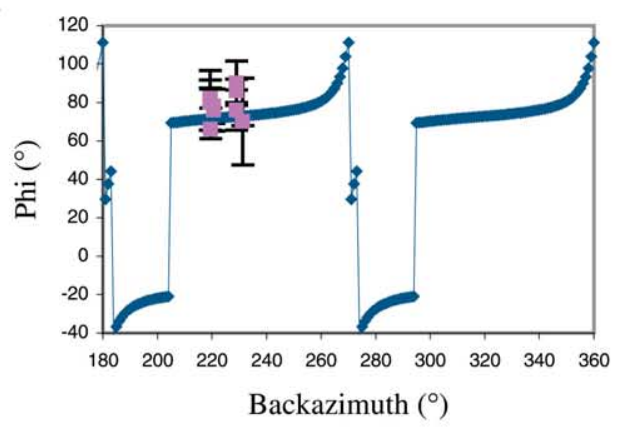

D

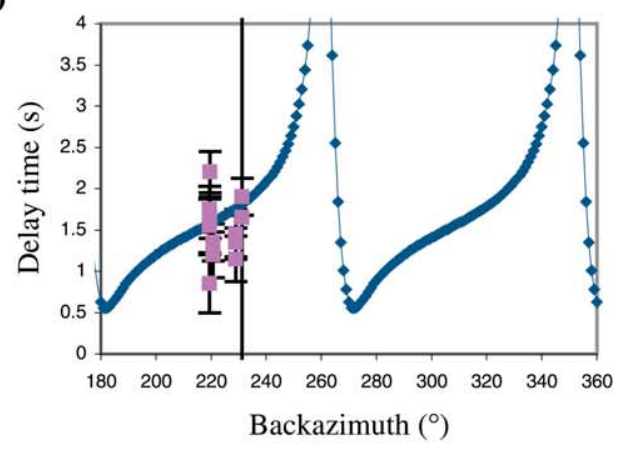


in lherzolites. Major wrench faults such as the Alem Paraiba and Igarata faults represent structures in which strain is localized and a strong LPO is expected to develop in the lithospheric mantle.

For several stations located along the Ribeira belt, $\phi$, although retrieved from good-quality data, varies between $\mathrm{N} 060^{\circ} \mathrm{E}$ and $\mathrm{N} 080^{\circ} \mathrm{E}$. Under the assumptions that the anisotropic medium possesses a hexagonal symmetry with a horizontal axis, and that anisotropy is restricted to a single homogeneous layer, one should expect no large azimuthal variation in the splitting parameters retrieved at a single station from $\mathrm{S}$-waves propagating with a near-vertical incidence. The observed variation may result from laterally varying anisotropy, dipping axis of symmetry or presence of several anisotropic layers. The similarity of splitting parameters obtained at two nearby stations (e.g. ALP and TRRB) precludes short-scale variations of anisotropy.

Silver and Savage [43] have shown that when two anisotropic layers are present beneath a station, splitting parameters measured assuming a single anisotropic layer will display coherent azimuthal variations. We performed two-layer modeling in order to explain the dependence of the values with the backazimuth. Systematic testing of all possible solutions would generate a large amount of models difficult to handle. We therefore restricted our models to situations having a geological meaning.

Modeling has been performed for several stations located in the northern part of the Ribeira belt, but only results obtained at stations TRRB and JFOB are presented. The most popular model of two-layers anisotropy is to consider that the lower layer corresponds to sublithospheric mantle and the upper layer to the 'orogenic' lithosphere. Two different situations have then been modeled for stations TRRB and JFOB (Figs. 10 and 11) with the anisotropy in the lower layer correspond-

Fig. 11. Apparent $\phi$ and $\mathrm{d} t$ vs. backazimuth of the incoming wave at stations TRRB (A,B) and JFOB (C,D), modeled using two layers of anisotropy (upper layer: $\phi_{1}=65^{\circ}, \mathrm{d} t_{1}=1 \mathrm{~s}$; lower layer: $\phi_{2}=220^{\circ}, \mathrm{d} t_{2}=0.8 \mathrm{~s}$ ).
A

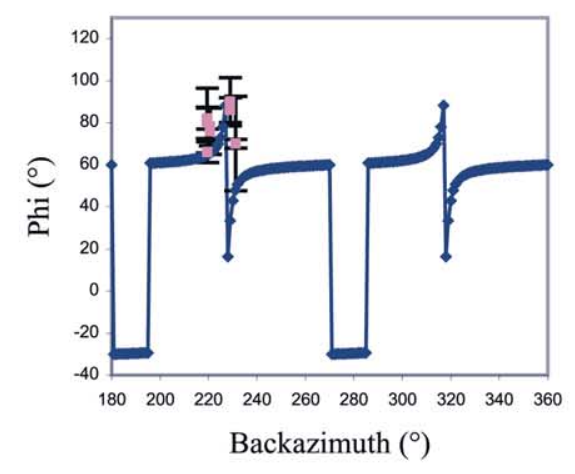

B

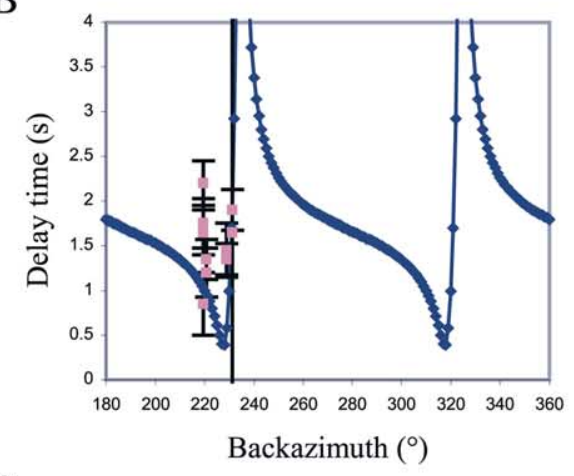

$\mathrm{C}$

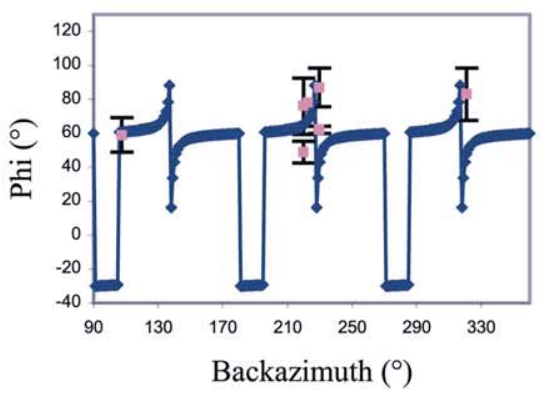

D

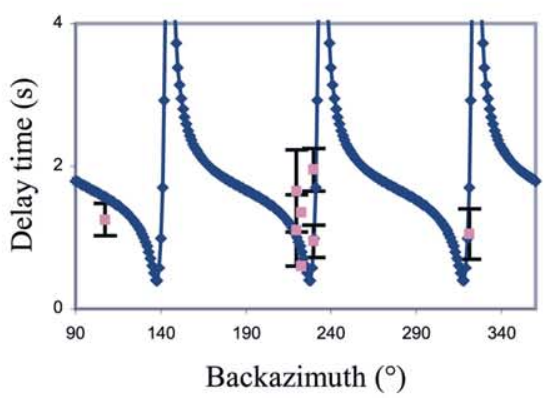


ing either to the HS3-Nuvel 1A [35] or to the T22A [36] APM $\left(\phi_{2}=253^{\circ}\right.$ or $\phi_{2}=283^{\circ}$ respectively). In both models, the fast $\mathrm{S}$-wave polarization in the upper layer is parallel to the structural trend of the Ribeira belt $\left(\phi_{1}=65^{\circ}\right)$. The delay times chosen for each layer have been calculated considering $5 \%$ of intrinsic anisotropy and a 100 $\mathrm{km}$-thick upper layer $\left(\mathrm{d} t_{1}=1 \mathrm{~s}\right)$. For the lower layer, we check the influence of the delay time on the fitting of the model with the data. Increasing the lower-layer anisotropy has slight effects on the apparent $\phi$ distribution and only shifts the apparent $\mathrm{d} t$ towards larger values. Only models with $\mathrm{d} t_{2}=0.8 \mathrm{~s}$ are shown in this paper. In model $1, \phi_{1}$ and $\phi_{2}$ are almost parallel. There is thus a good vertical coherence between both anisotropic layers and the apparent polarization of the fast split S-wave remains close to $70^{\circ}$. This model does not account for the data dispersion observed at stations TRRB and JFOB. Model 2 (Fig. 10B) also failed to simulate the observed variations at both stations.

Ozalaybey and Savage [44] have shown that when teleseismic S-waves propagate across two seismically anisotropic layer, the apparent splitting parameters display a large variability for waves with backazimuth close to the fast or slow axis of the bottom layer. As the mean backazimuth for events arriving from the Tonga and recorded at $\mathrm{TRRB}$ is ca. $\mathrm{N} 220^{\circ} \mathrm{E}$, this direction was used as anisotropy direction in the lower layer $\left(\phi_{2}=220^{\circ}, \mathrm{d} t_{2}=0.8 \mathrm{~s}\right.$ for the lower and $\phi_{1}=65^{\circ}, \mathrm{d} t_{1}=1 \mathrm{~s}$ for the upper layer). This model results in a large variation of the apparent splitting parameters for backazimuths around $220^{\circ}$ that fit well with splitting parameters observed at TRRB and JFOB (Fig. 11). If $\phi_{1}$ and $\phi_{2}$ are inverted, the fit with the data obtained at TRRB and JFOB is slightly deteriorated. However, the difference between these two models should only be evaluated by using data with a better backazimuthal coverage.

Although these models have been performed on a data set with a poor backazimuthal coverage, they suggest that a contribution of the lithospheric and the asthenospheric mantle cannot be ruled out. Models with an upper-layer anisotropy corresponding to the structural trend of the Ribeira belt and a lower-layer anisotropy corresponding to the HS3-Nuvel 1A [35] or the T22A [36] APM failed to satisfactorily fit the observed splitting parameters. The best fit was obtained with a lower-layer anisotropy close to the main backazimuth of the core shear waves used in this study. This direction, however, has no clear geological meaning and this suggests that the dispersion of the direction of the fast split shear wave polarization observed in the central Ribeira belt reflects a greater complexity than the simple two-layer models. Schimmel et al. [32], for instance, have shown that body wave velocities are abnormally high beneath the central Ribeira belt and this may suggest a complex lithospheric structure at depth (fossil slab?).

\section{Conclusion}

Shear wave splitting parameters retrieved at stations deployed in southeastern Brazil around the southern termination of the São Francisco craton are organized in a coherent pattern. Southwest of the craton, in the Brasilia belt, the fast split S-waves are coherently polarized in a direction $\sim \mathrm{N} 125^{\circ} \mathrm{E}$, i.e. parallel to the structural trend of the belt. Southeast of the craton, the fast split S-waves are polarized in a plane trending N060 $080^{\circ} \mathrm{E}$, parallel to the Ribeira belt.

A model of asthenospheric flow around the southern termination of the craton may explain part of the data set, but fails to account for both the anisotropy pattern in Ribeira and Brasilia belts. A network of large-scale wrench faults characterizes the central Ribeira belt. The orientation of the fast split shear wave polarization plane is parallel to the trend of the faults, and delay times measured at nearby stations are among the largest ever observed (average of $2.4 \mathrm{~s}$ ). Such large delay times require either $11 \%$ of intrinsic anisotropy for an average lithospheric thickness of $100 \mathrm{~km}$, or an asthenospheric contribution. In this latter case, anisotropy within the sublithospheric mantle should be close to the anisotropy within the lithospheric mantle implying either (1) a parallelism of the anisotropies respectively frozen in the lithosphere and generated in the asthe- 
nosphere due to the ongoing deformation that accommodates plate motion, or (2) the existence of a single tectonic fabric in the lithosphere and the asthenosphere, meaning that no decoupling occurred since Neoproterozoic times.

The first hypothesis is supported by the parallelism between the HS3-Nuvel 1A APM and the structural trend of the Ribeira belt but not by the results of the two-layer models. However, these models are poorly constrained due to the limited backazimuthal coverage of the events used in this study. The second hypothesis is in agreement with the suggestion by VanDecar et al. [31] and Schimmel et al. [32] that no decoupling occurred within the upper mantle beneath southeastern South America since the opening of the Atlantic Ocean. This suggestion, inferred from the observation of a low-velocity anomaly beneath the Paraná basin interpreted as the fossil conduit of the Tristan da Cunha plume, implies that no deformation would be produced in the asthenospheric mantle to accommodate the absolute plate motion of South America.

In any case, it seems difficult to interpret the pattern of anisotropy obtained in southeastern Brazil without considering a contribution of both the lithospheric and sublithospheric mantle. A strong signature of the major wrench faults in the observed anisotropy is a conclusion difficult to avoid. The good corrrelation of the orientation of the polarization plane of the fast S-wave with the structural trend of the Brasilia belt also favors a lithospheric origin. On the other hand, a contribution of the sublithospheric mantle is likely since it may explain the dispersion of the splitting parameters and also part of the large $\mathrm{d} t$ recorded above lithospheric-scale shear zone. However, simple lithosphere-asthenosphere models fail to account for the bulk of the anisotropy pattern, and this suggests that the deep structure beneath southeastern Brazil is more complex than suspected.

\section{Acknowledgements}

This work benefited from financial support from $\mathrm{CNPq} / \mathrm{CNRS}$ collaborative program (pro- cesso no. 910144/98-2 and PICS763), CAPES/COFECUB collaborative program (no. 287/99-II) and CNRS (Programme Interieur de la Terre). Support from the INSU lithoscope and broadband networks and from the French Embassy in Brazilia is acknowledged. We are indebted to $\mathrm{S}$. Chevrot, V. Levin and an anonymous reviewer for their helpful comments, to J. 'Zè' Roberto Barbosa for field, laboratory and administrative assistance and to A. Tommasi for field assistance and fruitful discussions.[BARD]

\section{References}

[1] P.G. Silver, Seismic anisotropy beneath the continents: probing the depths of geology, Ann. Rev. Earth Planet. Sci. 24 (1996) 385-432.

[2] M.K. Savage, Seismic anisotropy and mantle deformation: what have we learned from shear wave splitting?, Rev. Geophys. 37 (1999) 65-106.

[3] A. Nicolas, N.I. Christensen, Formation of anisotropy in upper mantle peridotites, Geodyn. Ser. 16 (1987) 111-123.

[4] V. Babuska, M. Cara, Seismic Anisotropy in the Earth, Kluwer Academic Publishers, 1991, 217 pp.

[5] W. Ben-Ismail, D. Mainprice, An olivine fabric database: an overview of upper mantle fabrics and seismic anisotropy, Tectonophysics 296 (1998) 145-157.

[6] A. Tommasi, B. Tikoff, A. Vauchez, Upper mantle tectonics: three-dimensional deformation, olivine crystallographic fabrics and seismic properties, Earth Planet. Sci. Lett. 168 (1999) 173-186.

[7] Y. Hasui, C.D.R. Carneiro, A.M. Coimbra, The Ribeira folded belt, Rev. Bras. Geocienc. 5 (1975) 257-266.

[8] M. Egydio-Silva, A. Vauchez, J. Bascou, J. Hippertt, High-temperature deformation in the Neoproterozoic transpressional Ribeira belt, southeast Brazil, Tectonophysics 352 (2002) 203-224.

[9] A. Vauchez, A. Tommasi, Wrench faults down to the asthenosphere: geological and geophysical evidence and thermo-mechanical effects, in: F. Storti, Holdsworth, R.E., Salvini, F. (Eds.), Intraplate Strike-Slip Deformation Belts, The Geological Society of London, London, 2003, pp. 15-34.

[10] M. Assumpção, D.E. James, A.J. Snoke, Crustal thickness in SE brazilian shield by receiver function analysis: implications for isostatic compensation, J. Geophys. Res. 107 (B1) (2002) ESE2-1-14.

[11] L.P. Vinnik, L.I. Makeyeva, A. Milev, A.Y. Usenko, Golbal patterns of azimuthal anisotropy and deformations in the continental mantle, Geophys. J. Int. 111 (1992) 433 447.

[12] D. Mainprice, G. Barruol, W. BenIsmail, The seismic anisotropy of the Earth's mantle: from single crystal to polycrystal, Geophys. Monogr. 117 (2000) 237-264. 
[13] J.M. Kendall, P.G. Silver, Investigating causes of $D^{\prime \prime}$ anisotropy, Geodyn. Ser. 28 (1998) 97-118.

[14] J. Wookey, J.M. Kendall, G. Barruol, Mid-mantle deformation inferred from seismic anisotropy, Nature 415 (2002) 777-780.

[15] D.E. McNamara, T.J. Owens, P.G. Silver, F.T. Wu, Shear wave anisotropy beneath the Tibetan Plateau, J. Geophys. Res. 99 (B7) (1994) 13655-13665.

[16] G. Herquel, G. Wittlinger, J. Guilbert, Anisotropy and crustal thickness of Northern-Tibet. New constraints for tectonic modelling, Geophys. Res. Lett. 22 (1995) 19251928.

[17] G. Barruol, D. Mainprice, A quantitative evaluation of the contribution of crustal rocks to the shear wave splitting of teleseismic SKS waves, Phys. Earth Planet. Inter. 78 (1993) 281-300.

[18] D. Mainprice, P.G. Silver, Interpretation of SKS-waves using samples from the subcontinental lithosphere, Phys. Earth Planet. Inter. 78 (1993) 257-280.

[19] M. Heintz, E. Debayle, A. Vauchez, M. Assumpção, Seismic anisotropy and surface wave tomography of South America, AGU Fall Meeting, San Francisco, 2000.

[20] P. Bormann, G. Gruenthal, R. Kind, H. Montag, Upper mantle anisotropy beneath Central Europe from SKS wave splitting: effects of absolute plate motion and lithosphere-asthenosphere boundary topography?, J. Geodyn. 22 (1996) 11-32.

[21] P.G. Silver, W.W. Chan, Implications for continental structure and evolution from seismic anisotropy, Nature 335 (1998) 34-39.

[22] A. Vauchez, A. Nicolas, Mountain-building: strike-parallel motion and mantle anisotropy, Tectonophysics 185 (1991) 183-201.

[23] D.E. James, M. Assumpção, Tectonic implications of S-wave anisotropy beneath SE Brazil, Geophys. J. Int. 126 (1996) 1-10.

[24] G. Barruol, P.G. Silver, A. Vauchez, Seismic anisotropy in the eastern United States: deep structure of a complex continental plate, J. Geophys. Res. 102 (B4) (1997) 83298348.

[25] G. Barruol, A. Souriau, A. Vauchez, J. Diaz, J. Gallart, J. Tubia, J. Cuevas, Lithospheric anisotropy beneath the Pyrenees from shear wave splitting, J. Geophys. Res. 103 (B12) (1998) 30039-30053.

[26] W. Ben-Ismail, G. Barruol, D. Mainprice, The Kaapvaal craton seismic anisotropy: petrophysical analyses of upper mantle kimberlite nodules, Geophys. Res. Lett. 28 (2001) 2497-2500.

[27] A. Tommasi, A. Vauchez, R. Russo, Seismic anisotropy in ocean basins: Resistive drag of the sublithospheric mantle?, Geophys. Res. Lett. 23 (1996) 2991-2994.

[28] P.G. Silver, D. Mainprice, W. BenIsmail, A. Tommasi, G. Barruol, Mantle structural geology from seismic anisotropy, Spec. Publ. Geochem. Soc. 6 (1999) 79-103.

[29] R. Trompette, Geology of Western Gondwana (2000-500
Ma): Pan-African-Brasiliano Aggregation of South America and Africa, A.A. Balkema, 1994, 350 pp.

[30] M.C. CamposNeto, R. Caby, Terrane accretion and upward extrusion of high-pressure granulites in the Neoproterozoic nappes of Southeast Brazil: petrologic and structural constraints, Tectonics 19 (2000) 669-687.

[31] J.C. VanDecar, D.E. James, M. Assumpção, Seismic evidence for a fossil mantle plume beneath South America and implications for plate driving forces, Nature 378 (1995) 25-31.

[32] M. Schimmel, M. Assumpção, J.C. VanDecar, Upper mantle seismic velocity structure beneath SE Brazil from P- and S-wave travel time inversion, J. Geophys. Res. 108 (2001) 10.1029/2001JB000187.

[33] P.G. Silver, W.W. Chan, Shear wave splitting and subcontinental mantle deformation, J. Geophys. Res. 96 (B10) (1991) 16429-16454.

[34] C.J. Wolfe, P.G. Silver, Seismic anisotropy of oceanic upper mantle: shear wave splitting methodologies and observations, J. Geophys. Res. 103 (1998) 749-771.

[35] A.E. Gripp, R.G. Gordon, Current plate velocities relative to the hotspots incorporating the NUVEL-1 global plate motion model, Geophys. Res. Lett. 117 (1990) 1109_ 1112.

[36] S. Wang, R. Wang, Current plate velocities relative to hotspots: implications for hotspot motion, mantle viscosity and global reference frame, Earth Planet. Sci. Lett. 189 (2001) 133-140.

[37] G. Silveira, E. Stutzmann, D.A. Griot, J.P. Montagner, L.M. Victor, Anisotropic tomography of the Atlantic ocean from Rayleigh surface waves, Phys. Earth Planet. Inter. 106 (1998) 257-273.

[38] G. Silveira, E. Stutzmann, Anisotropic tomography of the Atlantic Ocean, Phys. Earth Planet. Inter. 132 (2002) 237 248.

[39] S. VanderLee, D. James, P. Silver, Upper mantle S velocity structure of central and western South America, J. Geophys. Res. 106 (2001) 1-14.

[40] M.J. Fouch, K.M. Fischer, E.M. Parmentier, M.E. Wysession, T.J. Clarke, Shear wave splitting, continental keels, and patterns of mantle flow, J. Geophys. Res. 105 (2000) 6255-6275.

[41] S. VanderLee, G. Nolet, Upper mantle S velocity structure of North America, J. Geophys. Res. 102 (B10) (1997) 22815-22838.

[42] M. Rabinowicz, A. Nicolas, J.L. Vigneresse, A rolling mill effect in asthenosphere beneath oceanic spreading centers, Earth Planet. Sci. Lett. 67 (1984) 97-108.

[43] P.G. Silver, M.K. Savage, The interpretation of shearwave splitting parameters in the presence of two anisotropic layers, Geophys. J. Int. 119 (1994) 949-963.

[44] S. Ozalaybey, M.K. Savage, Double-layer anisotropy resolved from S phases, Geophys. J. Int. 117 (1994) 653664. 